\section{Short duration antibiotic therapy for native joint arthritis caused by Neisseria infection?}

We read with great interest the article "Two weeks versus four weeks of antibiotic therapy after surgical drainage for native joint bacterial arthritis: a prospective, randomised, non-inferiority trial" by Gjika et al. ${ }^{1}$ As staff members of a French Regional Referral Centre for complex bone and joint infections, we want to share our experience with short-duration antibiotic treatment for native joint arthritis caused by Neisseria gonorrhoeae $(\mathrm{Ng})$ and Neisseria meningitidis ( $\mathrm{Nm})$.

We conducted a retrospective study including all patients with arthritis caused by Gram-negative cocci treated in our institution from January 2018 to July 2020.
Ten patients were included (seven men, three women; median age 34 years; table 1). Most patients had monarthritis $(n=6)$; knees were the most frequently affected joints $(n=7)$. Fever was inconsistent $(n=5)$. Blood culture analyses were performed for nine patients and were positive for three patients. All but two patients (because absence of joint fluid) underwent joint aspiration. Direct examination and bacterial culture were positive in five and six of eight patients, respectively. Diagnoses were made using PCR of synovial fluid in two patients (\#7 and \#8) because their bacterial culture were negative without explanation (in particular no prior antibiotic therapy), antibiotic sensitivity could not be assessed for them. Six patients were infected with $\mathrm{Ng}$ and four with $\mathrm{Nm}$. $\mathrm{Ng}$ was always resistant to ciprofloxacin and exhibited intermediate sensitivity to penicillin G. Nm was always sensitive to amoxicillin with a minimal inhibitory

\begin{tabular}{|c|c|c|c|c|c|c|c|c|c|c|}
\hline & $\begin{array}{l}\text { Gender, } \\
\text { age (years) }\end{array}$ & $\begin{array}{l}\text { Infected } \\
\text { joints }\end{array}$ & & $\begin{array}{l}\text { Microbiological } \\
\text { diagnosis }\end{array}$ & & Bacteria & & Treatment & & $\begin{array}{l}\text { Clinical } \\
\text { outcome at } \\
2 \text { months }\end{array}$ \\
\hline & & & Blood culture & Synovial fluid & Other & & $\begin{array}{l}\text { Antibiotic and } \\
\text { duration }\end{array}$ & Surgery & Other & \\
\hline 1 & $M, 47$ & $\begin{array}{l}\text { Left thumb, } \\
\text { ankles }\end{array}$ & Positive & ND & $\begin{array}{l}\text { Oropharyngeal Ng } \\
\text { positive PCR }\end{array}$ & $\begin{array}{l}\text { Neisseria } \\
\text { gonorrhoeae }\end{array}$ & $\begin{array}{l}\text { Ceftriaxone IV, } 2 \\
\text { g/day, } 7 \text { days }\end{array}$ & No & $\begin{array}{l}\text { NSAIDs, } 2 \\
\text { weeks }\end{array}$ & $\begin{array}{l}\text { Complete } \\
\text { resolution }\end{array}$ \\
\hline 2 & $F, 45$ & Right knee & ND & $\begin{array}{l}\text { Direct } \\
\text { examination: } \\
\text { positive (GNC) } \\
\text { Culture: positive } \\
\text { PCR: positive }\end{array}$ & $\begin{array}{l}\text { Oropharyngeal, } \\
\text { genital and anal Ng } \\
\text { PCR positive }\end{array}$ & $\begin{array}{l}\text { Neisseria } \\
\text { gonorrhoeae }\end{array}$ & $\begin{array}{l}\text { Ceftriaxone IV, } 2 \\
\text { g/day, } 7 \text { days }\end{array}$ & No & No & $\begin{array}{l}\text { Complete } \\
\text { resolution }\end{array}$ \\
\hline 3 & $M, 54$ & Left knee & Negative & $\begin{array}{l}\text { Direct } \\
\text { examination: } \\
\text { positive (GNC) } \\
\text { Culture: positive } \\
\text { PCR: ND }\end{array}$ & No & $\begin{array}{l}\text { Neisseria } \\
\text { gonorrhoeae }\end{array}$ & $\begin{array}{l}\text { Ceftriaxone IV, } 2 \\
\text { g/day, } 7 \text { days }\end{array}$ & No & No & $\begin{array}{l}\text { Complete } \\
\text { resolution }\end{array}$ \\
\hline 4 & $M, 54$ & Left knee & Negative & $\begin{array}{l}\text { Direct } \\
\text { examination: } \\
\text { positive (GNC) } \\
\text { Culture: positive } \\
\text { PCR: ND }\end{array}$ & No & $\begin{array}{l}\text { Neisseria } \\
\text { gonorrhoeae }\end{array}$ & $\begin{array}{l}\text { Ceftriaxone IV, } 1 \\
\text { g/day, } 7 \text { days }\end{array}$ & Yes & $\begin{array}{l}\text { Evacuation } \\
\text { punctures } \\
\text { before surgery } \\
\text { and } \\
\text { NSAIDs, } 4 \\
\text { weeks }\end{array}$ & $\begin{array}{l}\text { Complete } \\
\text { resolution }\end{array}$ \\
\hline 5 & $\mathrm{~F}, 18$ & Left hip & Positive & $\begin{array}{l}\text { Direct } \\
\text { examination: } \\
\text { positive (GNC) } \\
\text { Culture: positive } \\
\text { PCR: positive }\end{array}$ & No & $\begin{array}{l}\text { Neisseria } \\
\text { meningitidis C }\end{array}$ & $\begin{array}{l}\text { Cefotaxime IV } \\
200 \mathrm{mg} / \mathrm{kg} / \mathrm{day}, \\
\text { then amoxicillin } \\
\text { IV, } 200 \mathrm{mg} / \mathrm{kg} / \\
\text { day, } 10 \text { days }\end{array}$ & Yes & $\begin{array}{l}\text { NSAIDs, } 2 \\
\text { weeks }\end{array}$ & $\begin{array}{l}\text { Complete } \\
\text { resolution }\end{array}$ \\
\hline 6 & $\mathrm{M}, 18$ & $\begin{array}{l}\text { Knees, elbows, } \\
\text { ankles, } \\
\text { shoulders, }\end{array}$ & Positive & $\begin{array}{l}\text { Direct } \\
\text { examination: ND } \\
\text { Culture: positive } \\
\text { PCR: positive }\end{array}$ & No & $\begin{array}{l}\text { Neisseria } \\
\text { meningitidis C }\end{array}$ & $\begin{array}{l}\text { Ceftriaxone IV } \\
4 \text { g/day, then } \\
\text { amoxicillin IV } \\
200 \mathrm{mg} / \mathrm{kg} / \text { day, } \\
7 \text { days }\end{array}$ & No & $\begin{array}{l}\text { NSAIDs, } 2 \\
\text { weeks }\end{array}$ & $\begin{array}{l}\text { Complete } \\
\text { resolution }\end{array}$ \\
\hline 7 & $M, 28$ & $\begin{array}{l}\text { Right knee } \\
\text { and ankle }\end{array}$ & Negative & $\begin{array}{l}\text { Direct } \\
\text { examination: } \\
\text { negative } \\
\text { Culture: negative } \\
\text { PCR: positive }\end{array}$ & No & $\begin{array}{l}\text { Neisseria } \\
\text { meningitidis C }\end{array}$ & $\begin{array}{l}\text { Ceftriaxone IV } 2 \\
\text { g/day, } 7 \text { days }\end{array}$ & Yes & $\begin{array}{l}\text { NSAIDs, } 2 \\
\text { weeks }\end{array}$ & $\begin{array}{l}\text { Complete } \\
\text { resolution }\end{array}$ \\
\hline 8 & $F, 24$ & Right knee & Negative & $\begin{array}{l}\text { Direct } \\
\text { examination: } \\
\text { negative } \\
\text { Culture: negative } \\
\text { PCR: positive }\end{array}$ & $\begin{array}{l}\text { Positive } \\
\text { oropharyngeal, } \\
\text { genital and anal } \\
\text { Ng PCR }\end{array}$ & $\begin{array}{l}\text { Neisseria } \\
\text { gonorrhoeae }\end{array}$ & $\begin{array}{l}\text { Ceftriaxone IV } 2 \\
\text { g/day, } 7 \text { days }\end{array}$ & No & $\begin{array}{l}\text { NSAIDs, } 2 \\
\text { weeks }\end{array}$ & $\begin{array}{l}\text { Complete } \\
\text { resolution }\end{array}$ \\
\hline 9 & H, 39 & $\begin{array}{l}\text { Left knee, } \\
\text { right foot, } \\
\text { right ankle, } \\
\text { right hand }\end{array}$ & Negative & ND & $\begin{array}{l}\text { Positive } \\
\text { oropharyngeal } \\
\mathrm{Ng} \text { PCR }\end{array}$ & $\begin{array}{l}\text { Neisseria } \\
\text { gonorrhoeae }\end{array}$ & $\begin{array}{l}\text { Ceftriaxone IV } 2 \\
\text { g/day, } 10 \text { days }\end{array}$ & No & $\begin{array}{l}\text { NSAIDs, } 2 \\
\text { weeks }\end{array}$ & In progress \\
\hline 10 & H, 16 & Left hip & Negative & $\begin{array}{l}\text { Direct } \\
\text { examination: } \\
\text { positive (GNC) } \\
\text { Culture: positive } \\
\text { PCR: positive }\end{array}$ & No & $\begin{array}{l}\text { Neisseria } \\
\text { meningitidis W }\end{array}$ & $\begin{array}{l}\text { Ceftriaxone IV } \\
2 \text { g/day, then } \\
\text { amoxicillin IV } \\
200 \mathrm{mg} / \mathrm{kg} / \text { day, } \\
7 \text { days }\end{array}$ & Yes & $\begin{array}{l}\text { NSAIDs, } 1 \\
\text { week }\end{array}$ & In progress \\
\hline
\end{tabular}

CRP, C-reactive protein; F, female; GNC, Gram negative cocci; IV, intravenous; M, male; MIC, minimum inhibitory concentration; ND, not done; Ng, Neisseria gonorrhoeae; Nm, Neisseria meningitidis; NSAID, non-steroidal anti-inflammatory drug.; 
concentration $(\mathrm{MIC})<0.125 \mathrm{mg} / \mathrm{L}$. The most common treatment was ceftriaxone for 7 days $(n=7)$. Two patients with $\mathrm{Nm}$ infections (\#5 and \#6) received first-line cefotaxime and ceftriaxone, respectively; after determination of the MICs, amoxicillin was used, thus yielding total treatment intervals of 7 and 10 days. Four patients required surgical drainage (\#4, \#5, \#7 and \#10). Concomitant non-steroidal anti-inflammatory drugs (NSAIDs) were used in eight patients (naproxen or ketoprofen), for reactive arthritis-like symptomatology, usually for 2 to 4 weeks. With a minimum of 2-month follow-up, outcomes were favourable for 8 out of 10 patients.

Most of native septic arthritis are caused by Gram-positive cocci ${ }^{2}$ Gram-negative cocci septic arthritis are rare and occur in $1 \%$ to $3 \%$ of affected patients. ${ }^{34}$ While oligoarthritis or polyarthritis are reported as the most common clinical presentation in literature, ${ }^{45}$ we observed a majority of patients with monarthritis, only one patient had oligoarthritis (\#7) and three had polyarthritis (\#1, \#6 and \#9). All patients exhibited arthritis in a large joint. The diagnosis of native arthritis can be made using blood cultures, direct examination and synovial fluid culture. Species-specific PCR can be performed to determine the presence of $\mathrm{Ng}$ in synovial fluid and specimens from other sites (eg, oropharyngeal, genital and rectal). Antibiotic susceptibility must be determined. $\mathrm{Ng}$ is typically resistant to penicillin and fluoroquinolones. ${ }^{4} \mathrm{Nm}$ is frequently sensitive to amoxicillin and thirdgeneration cephalosporins. ${ }^{6}$ The optimal therapy has not been established but our retrospective study supports the following hypothesis: ceftriaxone for $\mathrm{Ng}$ or amoxicillin for $\mathrm{Nm}$ (after determination of the MIC) for 7 days appears to be effective; surgical drainage is not required, except in patients for whom the infection cannot be controlled; meningococcal arthritis more frequently required surgery.

Overall, our study highlighted a completely different management of native joint arthritis due to $\mathrm{Ng}$ and $\mathrm{Nm}$ compared with others septic arthritis. ${ }^{2}$ Since it is a rare condition with scarce literature, one can consider shorter antibiotics duration of 7 to 10 days (ceftriaxone $2 \mathrm{~g} /$ day for $\mathrm{Ng}$ and amoxicillin 100 to 200 $\mathrm{mg} / \mathrm{kg} /$ day for $\mathrm{Nm}$ ). Surgical drainage is not always mandatory. Finally, NSAIDs are often required and can be safely used in combination with antibiotics, if needed.

Maïlys Ducours $\odot,{ }^{1}$ Samar El-Hout, ${ }^{2}$ Arnaud Desclaux, ${ }^{1}$ Hervé Dutronc, ${ }^{1}$ Thylbert Deltombe, ${ }^{1}$ Thomas Fauthoux ${ }^{1,2}$ François Vercruysse, ${ }^{2}$ Marie Kostine ${ }^{2},{ }^{2}$ Charles Cazanave ${ }^{1,3}$

${ }^{1}$ Infectious and Tropical Diseases Department, CHU Bordeaux, F-33000 Bordeaux, France

${ }^{2}$ Rheumatology Department, CHU Bordeaux, F-33000 Bordeaux, France

3INRAE, IHMC, USC EA 3671, Univ. Bordeaux, F-33000, Bordeaux, France
Correspondence to Professor Charles Cazanave, Infectious and Tropical Diseases Department, CHU Bordeaux, F-33000, Bordeaux, France;

charles.cazanave@chu-bordeaux.fr

Twitter Marie Kostine @MarieKostine

Contributors DM and EHS collected the date. DM and CC have written the article. $\mathrm{E}-\mathrm{HS}, \mathrm{AD}, \mathrm{HD}, \mathrm{VF}$ and $\mathrm{KM}$ contributed to the proofreading of the article. DM, CC, $E-H S, A D, H D, V F, K M, D T$ and $F T$ was in charge of patients during hospitalisation.

Funding The authors have not declared a specific grant for this research from any funding agency in the public, commercial or not-for-profit sectors.

Competing interests None declared.

Patient and public involvement Patients and/or the public were not involved in the design, or conduct, or reporting, or dissemination plans of this research.

\section{Patient consent for publication Not required.}

Ethics approval This work is consistent with the protection of personal health data and privacy under article 65-2, the amended Computer and Freedoms Act and the General Regulation of Personal Data Protection.

Provenance and peer review Not commissioned; internally peer reviewed.

(c) Author(s) (or their employer(s)) 2020. No commercial re-use. See rights and permissions. Published by BMJ.

\section{D) Check for updates}

To cite Ducours M, El-Hout S, Desclaux A, et al. Ann Rheum Dis Epub ahead of print: [please include Day Month Year]. doi:10.1136/annrheumdis-2020-218835

Received 10 August 2020

Accepted 14 August 2020

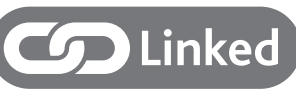

- http://dx.doi.org/10.1136/annrheumdis-2020-218882

Ann Rheum Dis 2020;0:1-2. doi:10.1136/annrheumdis-2020-218835

ORCID iDs

Maïlys Ducours http://orcid.org/0000-0001-7427-2314

Marie Kostine http://orcid.org/0000-0002-6729-6200

\section{REFERENCES}

1 Gjika E, Beaulieu J-Y, Vakalopoulos K, et al. Two weeks versus four weeks of antibiotic therapy after surgical drainage for native joint bacterial arthritis: a prospective, randomised, non-inferiority trial. Ann Rheum Dis 2019;78:1114-21.

2 Mathews CJ, Kingsley G, Field M, et al. Management of septic arthritis: a systematic review. Postgrad Med J 2008;84:265-70.

3 Parent du Chatelet I, Deghmane AE, Antona D, et al. Characteristics and changes in invasive meningococcal disease epidemiology in France, 2006-2015. J Infect 2017:74:564-74.

4 Bardin T. Gonococcal arthritis. Best Pract Res Clin Rheumatol 2003;17:201-8.

5 Masson-Behar $\mathrm{V}$, Jacquier $\mathrm{H}$, Richette $\mathrm{P}$, et al. Arthritis secondary to meningococcal disease. Medicine 2017;96:e7573.

6 Centre national de référence des Méningocoques. Rapport d'activité, 2014. Available: https://www.pasteur.fr/fr/file/3273/download?token=8UaruHXt 